Lebedeva, G.N. (2021). Literary magazine as a historical memory keeper. Scientific view on the modern problems of cultural heritage and arts in the context of social development. Klironomy, 1 (1), 32-42. Hlučín-Bobrovníky: "Anisiia Tomanek" OSVČ.

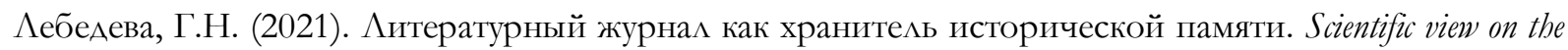
modern problems of cultural heritage and arts in the context of social development. Klironomy, 1 (1), 32-42. HlučínBobrovníky: "Anisiia Tomanek" OSVČ.

DOI: $10.47451 /$ her2021-05-001

EOI: $10.11249 /$ her2021-05-001

The paper is published in Crossref, Internet Archive, Google Scholar, Academic Resource Index ResearchBib, JGate, ISI, CiteFactor, ICI, eLibrary databases.

Galina N. Lebedeva Associate Professor, Candidate of Philosophical Sciences (PhD) Department of Philosophy Leningrad State University named after A.S. Pushkin St Petersburg, Russia

E-mail: gal_le@list.ru ORCID: 0000-0002-2755-2003

\title{
Literary magazine as a historical memory keeper
}

\section{Abstract:}

The study object was 19th-century Russian journalism as a social institution associated with preserving cultural heritage and historical memory. The issues of cultural heritage preservation in the Russian Empire of the first half of the 19th century are considered using a 19th-century literary magazine as an example. Journalism occupies no less a place in culture than art, morality, science and technology. Influencing the public consciousness, journalism is important, because addressing, it raises the question of public confidence in the authorities. Thus, journalists are the keepers of the heritage. This can contribute to the stability and development of society. In the course of the study, it was possible to trace how the journalistic and practical activities of writers, intellectuals and publishers contributed to the unification of publicists, statesmen and scientists and influenced the formation of public consciousness, as well as programs and institutions for the preservation of cultural heritage.

\section{Keywords:}

A.A. Guseynov, literary magazine, cultural heritage, journalism as a heritage, heritage keepers, control over information, publishing, institutional and non-institutional ways of heritage preservation.

\section{Галина Николаевна Аебедева}

к. филос. н., доцент кафедры кафелра фимософии

ГАОУ ВО $\Lambda$ О «Аенинградский государственный университет им. А.С. Пушкина» 
Санкт-Петербург, Россия

E-mail: gal_le@list.ru

ORCID: 0000-0002-2755-2003

\section{Митературный журнал как хранитемь исторической памяти}

\section{Aннотачия:}

Объектом исследования являлась русская журналистика XIX века как социальный институт, связанный с хранением культурного наследия и исторической памяти. На примере митературного журнала XIX века рассмотрены вопросы по сохранению культурного наследия в Российской империи в первой половине XIX века. Журналистика в культуре занимает не меньшее место, чем искусство, мораль и наука и технологии. ВАияя на общественное сознание, журналистика важна, потому что, обращаясь к нему, ставит вопрос о доверии общества к власти. А журналисты, тем самым, являются хранителями наследия. Это может способствовать стабильности и развитию общества. В ходе исследования удалось проследить, как публицистическая и практическая деятельность митераторов, интелмектуалов и издателей способствовали объеАинению публицистов, государственных деятелей и ученых и влияли на формирование общественного сознания, а также программы и учрежления по сохранению культурного наследия.

\section{Ключевые слова:}

А.А. Гусейнов, митературный журнал, культурное наследии, публицистика как наследие, хранители наследия, контроль наА информацией, издательская Аеятельность, институциональный и неинституциональный способы сохранения наследия.

\section{Introduction}

Ideas about heritage and the memory of the past are always relevant for a person. After all, they act as one of the areas where identity is formed and ask questions: Who am I? Who are we? Where are we from? In the chain of 'past present - future', connections with the past, which contribute to the identity and help not only an individual to navigate, are created. The collective experience, the hierarchy of ideas, sources of knowledge about the past are the bases for storing cultural heritage. Simultaneously, in the chain of 'past-present-future', urgent needs are set for the whole society and the people, as well as for the country and humanity as a whole. Are intellectuals and the media responsible for their role in influencing society? The question is, what kind of assessment is this, who creates it and how? What is the role of intellectuals in journalism? Do journalists influence society?

The study object was 19th-century Russian journalism as a social institution associated with preserving cultural heritage and historical memory. 
The purpose of the review is to study the list of sections, reviews and translations, literary criticism, chronicles of current events in the world published in this periodical on the example of the journal Russian Bulletin. All these sections created a specific cultural system, which can be considered as a cultural heritage.

The study objectives were:

- analyze formal and informal structures, institutions and practices of communication in journalism, in which cultural heritage was created and preserved on the example of periodicals in 19th-century Russia;

- $\quad$ fix the concepts describing the storage of cultural heritage;

The comparative historical method and the method of historical reconstruction were used, which is necessary to determine the concepts and mechanisms of heritage storage in journalism of the 19th century (including the content of periodicals: articles, notes, reviews, etc.). The system method helps to consider the contents of the log as a complete system.

\section{The issue of the considering journalism relevance as a cultural heritage category}

All arguments aimed at studying the past, if they are logically and consistently organized, assess the present, creating a hierarchy of values and concepts. The concepts of 'cultural heritage', 'historical culture', 'traditions', etc. are introduced into circulation. About what is 'cultural heritage' and the literature on this issue was considered earlier (Lebedeva, 2020; Lebedeva, 2021).

There is no heritage at all; it is always concrete. Forms of heritage and knowledge about heritage are sources of knowledge about the past. As I.M. Savelyeva and A.V. Poletaev write in the book Social Representations of the Past: Sources and Representations (2005), "there are several types of knowledge focused on the past, and different sources of knowledge about the past-oral, visual and audiovisual, written" (Savelyeva \& Poletaev, 2015).

Except that the heritage is preserved in specific knowledge or sources, written heritage forms can be manuscripts, diaries, personal archives and documents. In this article, the legacy in printed form, i.e., the literary magazines of 19th-century Russia are considered. One of the methodological works that shows a systemepistemological approach to how to work with the heritage of the historical past is a thorough philosophical work Historical Cognition: A System-Epistemological Approach by A. I. Rakitov (Rakitov, 2014). 
The need to consider periodicals and journalism as a legacy was actualized in 1962 by the Academician of the USSR Academy of Sciences Sigurd Ottovich Schmidt. Knowledge about the past is impossible without clarifying the role of historical science, historical knowledge and ideas in the process of forming political ideas and programs of various social forces, the degree of their dissemination and perception through mass historical literature and periodicals (Schmidt, 1962).

'Historical culture' is a new concept, "with the help of which the hierarchical unity of ideas about the past, accumulated and transmitted in the collective experience of mankind is described". It is possible to note the research expressed by the collective monograph Historical Culture of Imperial Russia: Formation of Ideas about the Past (2012). Thus, the researchers managed to combine many complex phenomena of this period (Dmitriev, 2012).

What exactly are these ideas and programs of various social forces. How can they be expressed?

1. It seems that in the open access, these are periodicals, magazines, almanacs, electronic versions of which are already available on the Internet. At the same time, many of them are still waiting for modern reading and understanding.

2. The study of heritage can also be epistolary, in the form of diaries, memoirs, correspondence, many of them are publicly available on the Internet.

3. The national culture also exists in the form of knowledge through the programs of various social forces, the degree of their dissemination and perception in the mass history of literature and periodicals. But the list of periodicals is extensive, available in the public domain, but little studied, e.g., these are the periodicals Russian Bulletin, Citizen, Russian Review, etc.

\section{The journalism place in the public consciousness in comparison with science and art}

Over the past two and a half centuries, the history of the magazine business has gone from the formation of general literary journals, the popularization of social issues, the emergence of highly specialized scientific and then sociological journals, and the decline of the book and publishing boom since the late 1990s.

Journalism and thick literary magazines appeared in Russia in the early 18th century. In 1759, private magazines appeared there. After the Free Printing Houses Degree in 1783, they appeared too. The decree on free printing houses introduced state censorship, which was first dealt with by the police department, and in 1796 special censorship committees were formed. Their organization process and the range of problems began to be considered even in the pre-revolutionary period. 
These are the studies of Lemke (Lemke, 1904), Lisovsky (Lisovsky, 1915), P.K. Schebalsky (Shchebalsky, 1862). In the mid-19th century, magazines and periodicals, speaking in modern language, were a specific type not only in communication but also in the practice of that time.

Such social changes as the urban lifestyle, the appearance of novelties and inventions, trade stimulated interest and demand for them. The accumulation of people in cities leads to the appearance of a mass reader and the public, a typical urban mass phenomenon. The appearance of journalism is attributed to the era when there are means for reproducing literary works in large editions, i.e., printing. The very word journalism (from the word public, public) implies an appeal to policy issues, an expression of the views of society and readers.

The increasing role of education, literary salons and clubs become a ubiquitous phenomenon. Initially, they were attended by high dignitaries, ministers (Lebedeva, 2021), the nobility, and, later, fulfilling the needs of the state, specialized departmental journals, e.g., Journal of the Ministry of State Property (1841-1918), Journal of the Ministry of Railways (1845-1865), Journal of the Ministry of Justice (1859-1868), etc. began to appear.

Today, both sociologists and philosophers have an interest in journalism, e.g., the symposium Philosophy and Journalism in the IF RAS, dedicated to Krayevsky as a journalist (Philosophy and Journalism, 2020).

Speaking about the union of philosophy and journalism, A.A. Huseynov noted that Krayevsky was one of the first in Russia who "gave journalism a nationwide scale, he brought some journalism into public affairs, considered journalism as an important cementing foundation of public space" (Philosophy and Journalism, 2020).

The mainline of Krayevsky's periodical was that journalism expresses the opinion of society, the voice of the people. According to Krayevsky's plan, the Golos Magazine could coincide with the government, or, on the contrary, oppose the government and officials. The most important thing is that the periodical expresses the independent social opinion and the people opinion. Journalism is often in opposition and often flirts with government and security departments of the government. The generic feature of Russian journalism was the fact that they developed in close alliance with philosophy, history, and many other areas of science.

Writers, philosophers, historians created texts for magazines. Departments at universities, scientific societies, university business, academic forms began to be created when Russian philosophy, sociology, collected enough material for their 
formation. And later, the connection of philosophy with journalism did not stop, especially in the era of the Silver Age. In general, philosophy is linguistic through literature and journalism, and journalistic, because it is connected with society through journalism. Since the 1990s, political scientists, economists, and sociologists have taken a huge place in journalism. Many questions have come to the fore, but it is impossible to solve them without a philosophical analysis.

\section{Literary magazine structure}

The fact that specific individuals created Russian journalism is indisputable: this is everyday work, talented authors selection. All the classics of Russian literature have tried themselves in journalism. The journalist often acted in different roles: as a translator, compiler, civil servant.

Back in 1812, Dmitry Vasilyevich Dashkov (1789-1939) in the 1st part of St Petersburg Bulletin justified the structure of a literary magazine in the article Something about Magazines: "Everything can be part of such a magazine: literature, news about important discoveries in the sciences and arts, etc., but the main purpose of it should be criticism" (Stanko, 2003). He was the founder and one of the most active members of the literary society Arzamas, and in the last ten years of his life, he managed the Ministry of Justice (since 1832 as a minister). At that time, magazine's mission was also discussed in other circles and publications.

Firstly, magazines as a means of communication reflected the events of their time. Such sections of magazines as reviews, descriptions of facts and events appeared in periodicals as a kind of chronicle. The ability to attract readers and arouse public interest in such short and transient events requires great skill, especially when behind a string of repetitive, every day and simple events, you need to find very complex life processes that are important in the future. It shows the professionalism and tragedy of many magazines - a kind of short existence of many materials and publications.

Secondly, the magazines searched for new genres in fiction and poetry, and they placed translations of modern foreign literature, which later became classics. The initial task of the journal as a publication was to publish original texts and research, and therefore to introduce readers to these texts, after which it was the turn of literary review and subsequent criticism. In the future, the texts, which aroused some interest, were waiting for a secondary publication, but in a different form, e.g., in the form of a separate publication.

Thirdly, such more complex phenomena as conflicts, coups, revolutions and wars had to be covered not only, but there was a need for an analysis of 
international events. Moreover, scientific, political, economic congresses, research and events contributed to the formation of peculiar sections, which, in the future, contributed to the emergence of specialized scientific journals.

In general, the journals expanded their boundaries, showing interest in the types of knowledge that later took shape in Russia as philosophy, history, sociology, natural science, law, pedagogy, history and theory of culture and art.

\section{Like-minded people, institutions and social practice of the journal}

Another aspect is the social practice or the practice of the journal discourse. This is manifested in the fact that like-minded people gathered around him. In fact, there was not only a routine painstaking process of information exchange but also the specialization of knowledge. Gathering around itself not only like-minded people, each magazine represented a whole social trend not only in the ideological sense but also in literature and science.

Modern researchers believe that openness to burning problems makes journalism "a powerful spiritual support of public life, the resources and capabilities of which are not yet fully understood and in demand, while the devaluation of spiritual and moral values affects a variety of spheres of life" (Gromova, 2017).

During the period of significant changes, periodicals have always become a kind of space where leading scientists had the opportunity to update everything, connected not only with the needs of educating different people but also with the public consciousness formation. At the same time, magazines are an active specific sphere in which public consciousness formation takes place.

Journalism is something that is still being debated about how difficult to find a definition, give a characteristic, describe the purpose and role of journalism in society. Even Tretyakov in his textbook could not give one definition but gave five at once (Tretyakov, 2013).

Another huge point in the preservation of cultural heritage is the formal institutions, i.e. the participation of the authorities and the bureaucracy in the stabilization of many forms of practices. The authorities and the bureaucracy consider their mission not only to organize society but also to influence and control. Max Weber also showed that the bureaucratic authorities, officials, and political institutions not only exercise control but also have specific techniques and tools (tools). Both the collection of information about the past is carried out, and the features of storing such information are limited and determined with them. 
The bureaucracy determines, what documentation will be recorded and what will be opened, or vice versa closed. Unaware of this, the bureaucracy not only gives an idea of the past but also determines how the future will be seen. Thus, control over information is seen as an instrument of the social influence of the authorities.

Concerning journalism, the authorities carried out such forms as the activities of government and official publications, permission to operate and open publications, censorship, closure of publications and even arrests of journalists. Unofficial forms of heritage storage in journalism were underground publications or semi-legal ones.

Indeed, the process of forming ideas about the past, which is susceptible to the influence of bureaucracy, can be described as an institutional and consciously directed process of preserving heritage. These are always formal institutions controlled by the state: commissions, ministries, departments.

Conversely, there are always free and spontaneous, non-institutional ways of storing heritage-these are oral folk art, oral, visual and audiovisual, written sources, personal documents (diaries, letters, etc.) also take place.

"Journalism, unlike the media, is a social institution: it has pronounced forms of sociality, as one of the embodiments of public consciousness, experience and practice, as a way of spiritual self-organization of the social system. It comes to politics in this capacity, and not as an instrument at the disposal of certain political forces" (Korkonosenko, 2017).

As in any system, the following roles can be distinguished in journalism: writer (journalist), publisher, reader. As it develops, other roles appear, e.g., censor, editor, librarian, bibliographer, literary critic, and the specialization of journalists: music, political and other reviews - were evidence of the emergence of new professions.

\section{Discussion}

In the introduction, it was figuratively said that connections with the past are created in the chain of 'past - present - future'. It can be assumed that not only modern generations raise the question of identity. The past generations, who have created a legacy, are carriers of identity. Under what conditions will future generations look for their identity? Will they be able to rely on some heritage?

The question to identity "Who are we?" is connected with culture, not with political, economic differences. People define themselves using their origin, religion, language, customs, and social institutions. 
The article considers journalism of the 19th century in Russia as an established social institution. We know the opinion of Pierre Bourdieu that magazines performed the role of constructing the world. By selecting and interpreting the phenomena of reality, the magazines participated in a symbolic struggle for readers' perception of the social world, forcing them to see and evaluate reality in a certain way (Bourdieu, 1994). Journalism could occupy a specific niche, influencing politics, journalism facilitated identity, being a part of civil society. Addressing acute social problems, literary magazines awakened not only the educated strata, the intelligentsia of their time. The intelligible and understandable language helped educate and mobilize readers who were not very prepared for serious problems. What are modern readers? What are they interested in? What is the range of their problems? Whose position is the journalists expressing now, and will they be able to influence the world?

Another problem is that intellectual communities, professional writers, censors, form intellectual history and culture, influence its transmission and storage. Such a method is attempted in the work of R. Collins (Collins, 2002). This work can also be considered a new methodological approach to culture and the heritage preservation concerning 19th-century Russian journalism.

\section{Conclusion}

Thus, we can distinguish many stages of journalism from its formation to its heyday and decline. The content of thick literary journals, like literature in general, is organized as a huge social institution. The allocation of sections of criticism, bibliography, translations, and fiction led to the fact that the journal created a system. Currently, there are electronic media and online magazines, professions such as bloggers, copywriters, or when algorithmic or robotic journalism is created in automated journalism, creating news articles. Will they replace the paper magazine and the profession of a journalist? Will a thick literary magazine leave as a phenomenon and a system? After all, the system is an analogue of the order and storage of information. Or will journalism have acquired new forms, lead to new systems?

We know the opinion of Pierre Bourdieu that magazines performed the role of constructing the world. By selecting and interpreting the phenomena of reality, the magazines participated in a symbolic struggle for readers' perception of the social world, forcing them to see and evaluate reality in a certain way (Bourdieu, 1994). How will journalists now be able to express their civic position and influence the world? 
Another problem is that intellectual communities, professional writers, censors, form intellectual history and culture, influence its transmission and storage. Such a method is attempted in the R. Collins' work (Collins, 2002). This work can also be considered a new methodological approach to culture and the heritage preservation concerning Russian journalism of the 19th century.

Journalism occupies no less a place in culture than art, morality, science and technology. Influencing the public consciousness, journalism is huge, because addressing, it raises the question of public confidence in the authorities. And journalists, thus, are the keepers of the heritage. This can contribute to the stability and development of society.

\section{References:}

Bourdieu, P. (1994). Beginnings. Choses dites. (Trans.). Moscow. (in Russian)

Gromova, L.P. (2017). Modern journalism in the discourse of tradition. Journalism and Morality. Collection of articles based on the materials of the round table, 13. Vladikavkaz: North Ossetian State University named after K.L. Khetagurov. (in Russian)

Dmitriev, A.N. (Ed.) (2012). Historical culture of Imperial Russia: formation of ideas about the past. Moscow: Publishing House of the Higher School of Economics. (in Russian)

Collins, R. (2002). Sociology of philosophy: a global theory of intellectual change. (Trans. by N.S. Rozova and Y.B. Wertheim). Novosibirsk: Siberian Chronograph. (in Russian)

Korkonosenko, S.G. (2017). Political journalism. Moscow. (in Russian)

Lebedeva, G.N. (2021). HOMO ACADEMICUS. Part I. Scientific and Public organizations of the Russian Empire: between State Responsibility and Private Initiative. Eastern European bumanitarian collection of mini monographs. European Scientific e-Journal, 1 (7), 61-107. Hlučín-Bobrovníky: "Anisiia Tomanek" OSVČ. (in Russian)

Lebedeva, G.N. (2020). Philosophy of cultural heritage: scientific and public organizations of the Russian Empire. Eurasia: current issues of cultural heritage. European Scientific e-Journal, 3 (3), 51-61. Hlučín-Bobrovníky: “Anisiia Tomanek" OSVČ.

Lemke, M. (1904). Essays on the history of Russian censorship and journalism of the 19th century. St Petersburg. (in Russian) 
Lisovsky, N.M. (1915). Bibliography of the Russian periodical press. 1703-1900. Materials for the history of Russian journalism). Petrograd. (in Russian)

Rakitov, A.I. (2014). Historical cognition: A system-epistemological approach. Moscow: Direct-Media. (in Russian)

Savelyeva, I.M., Poletaev, A.V. (2015). Social representations of the past: sources and representations. Moscow. (in Russian)

Stanko, A.I. (2003). Journalism of the first quarter of the XIX century. History of Russian journalism of the 18th and 19th centuries: Textbook. (Gromov, L.P., Ed.), 182-183. St. Petersburg. (in Russian)

Tretyakov, V.T. (2013). How to become a famous journalist: A course of lectures on the theory and practice of modern Russian journalism. Moscow: Direct-Media. (in Russian)

Schmidt, S.O. (1962). On the subject of Soviet historiography and some principles of its periodization. History of the USSR, 1. (in Russian)

Shchebalsky, P.K. (1862). Historical information about censorship in Russia. St Petersburg. (in Russian)

Philosophy and Journalism (to A.A. Krayevsky 200th anniversary, 1810-1889). Symposium at the IF RAS on May 11, 2010. Retrieved March 10, 2009, from https://iphras.ru/page50602039.htm (in Russian) 